\title{
Biological Characteristics of Azov Anchovy (Engraulis encrasicolus maeoticus A.) in 2016-2017 and 2017-2018 Fishing Seasons
}

\author{
Mikhail Chesalin $^{1, *}\left(\mathbb{D}\right.$, Victor Nikolsky $^{1}$, Tatjana Yuneva $^{1}$
}

${ }^{1}$ A.O. Kovalevsky Institute of Biology of the Southern Seas, Russian Academy of Sciences, MRO IBSS, Leninskii ave., 38/3, Moscow, 119991, Russian Federation

\section{Article History}

Received 29 August 2019

Accepted 17 January 2020

First Online 29 January 2020

\section{Corresponding Author}

Tel.: +79780881627

E-mail: mike.chesalin@gmail.com

\section{Keywords}

Azov anchovy

Size

Age

Condition factor

Sex ratio

Growth

\begin{abstract}
Biological parameters of Azov anchovy from commercial catches in 2016/2017 and 2017/2018 fishing seasons were studied. During the first season, fishery was mainly based on fish of the 1st age group with an average length of $10.9 \mathrm{~cm} \mathrm{TL}$, while in $2017 / 2018$ on 2-year-old fish with length of $11.4 \mathrm{~cm}$. Parameters of the length-weight relationship were not different between sexes: for fish $<9.5 \mathrm{~cm} \mathrm{TL} a=0.00126, b=$ 3.719 , and for fish $\geq 9.5 \mathrm{~cm} \mathrm{a}=0.0207, b=2.475$. The sex ratio in overall was close to $1: 1$. The relative condition factor $\mathrm{Kn}$ and total lipids content were higher in OctoberNovember 2017/2018 than in 2016/2017 and gradually decreased to February-March in both seasons. The growth rate was also slightly higher in $2017 / 2018$. For both seasons, growth parameters in the von Bertalanffy equation were estimated as $\mathrm{L}_{\infty}=$ $13.0 \mathrm{~cm}, \mathrm{~W}_{\infty}=12.6 \mathrm{~g}, \mathrm{~K}=0.73 \mathrm{yr}^{-1}, \mathrm{t}_{\mathrm{o}}=-0.86 \mathrm{yr}$. Azov anchovy is lighter in weight than the Black Sea anchovy at the same length. The growth rate of Azov anchovy seems to be similar to the Black Sea anchovy for age groups 0 and 1, but declined as fish getting older.
\end{abstract}

\section{Introduction}

The European anchovy, Engraulis encrasicolus (Linnaeus, 1758) is represented by two subspecies or populations in the Azov-Black Sea basin: Azov anchovy (E. encrasicolus maeticus Alexandrov, 1927) and the Black Sea anchovy (E. encrasicolus ponticus, Puzanov, 1926). The taxonomic status of the Azov and Black Sea anchovies is still an ongoing dispute (Gücü et al., 2017). However, these anchovies considered as separate stocks, and their assessment, as well as recording to fisheries statistics and regulations were carried out separately (STECF, 2015; GFCM, 2014).

Unlike the Black Sea anchovy, which spends entire lifecycle in the Black Sea, Azov anchovy spawns and feeds in the Sea of Azov in summer, then migrates through the Kerch Strait to the Black Sea in OctoberNovember. The main overwintering area of Azov anchovy is located along the northern Caucasian coast to Georgia, sometimes even reaching the Turkish border (Chashchin, 1996). Düzgüneş et al. (2018) reported that Azov anchovy approaches the Turkey-Georgia border, and can move southwards along the coastline down to Turkish waters in summer. The results of the recent work (Gursalan et al., 2017) show the possibility that overwintering anchovy fished along the Turkish Eastern Anatolian coast may not exclusively originate from the northwestern shelf, but mainly from the eastern Black Sea basin and the Sea of Azov.

Anchovy biomass is characterized by very high spatial-temporal variability, as these fast-growing and short-lived fish respond very rapidly to environmental changes by recruitment success (Guraslan et al., 2014; Gücü et al., 2016). The biomass of the Azov Sea anchovy varied in range of 10-650 thousand tons during 19912016 (mean level was about 170 thousand tons), while 
Russian-Ukrainian landings were from 140 tons to 54.5 thousand tons (mean about 20 thousand tons) (Chashchin et al., 2015; Shlyakhov et al., 2018) (Figure 1). Thus, the average catch-to-stock ratio in 1991-2012 was approximately $11 \%$, but it sharply increased and reached $42-44 \%$ in 2015-2016. These data do not include catches of Azov anchovy of Turkish and Georgian fleets. The Russian-Ukrainian Commission on Fisheries in the Sea of Azov recommended an annual exploitation rate for Azov anchovy at the level $20-30 \%$ of its initial stock (Shlyakhov, 2015). The Commission annually approved total allowable catch (TAC) for Russia and Ukraine in 15-30 thousand tons until 2010, but in 20102018 the TAC was increased to $60-80$ thousand tons. The total catch of Azov anchovy in 2016 by Russia, Ukraine and Abkhazia was more than 75 thousand tons and for the first time in 25 years exceeded the TAC of 65 thousand tons. Therefore, one of the aims of the present study was to assess the condition of Azov anchovy population, including size and age structures, sexual composition, fatness, growth and other parameters after the intensive fishing pressure.

Moreover, there are numerous publications on biological and population parameters of the Black Sea anchovy, while the data on the Azov anchovy are very scarce and were published in the past century (Popova, 1954; Dement'eva, 1958; Kornilova, 1960; Volovik \& Kozlitina, 1983). Some data on the size-age composition of anchovies overwintering along the Crimean coast were reported by Zuyev with co-authors (Zuyev, 2014; Zuyev et al., 2014; and references therein), however, these data mainly related to mixed schools of the Azov and Black Sea anchovies.

\section{Materials and Methods}

Anchovy samples of approximately $1.5 \mathrm{~kg}$ (150-200 individuals) were randomly taken from commercial landings of fishing boats once a week (if possible) for two fishing seasons, lasting from October 2016 to March 2017 and from October 2017 to February 2018. The first catches were from the Sea of Azov and the Kerch Strait during the anchovy migration to the Black Sea, and then from a traditional wintering ground of Azov anchovy off the North Caucasus coast between Anapa and Sochi. The belonging of the anchovies to the Azov subspecies was checked and confirmed using the otolith length to width aspect ratio and the angle between rostrum and antirostrum as proposed by Vodyasova and Soldatov (2017). Overall, 3626 anchovies in 2016/2017 fishing season and 1705 fish in 2017/2018 were sampled from different catches (Table 1). Fish were measured and grouped in $0.5 \mathrm{~cm}$ intervals of fork length (FL), counted and weighed to assess the size-weight composition and lengthfrequency distribution of the catches.

For detailed biological analysis, at least ten specimens were randomly taken from each $0.5 \mathrm{~cm}$ size class. A total of 1745 anchovies were measured in the total ( $T L)$, fork (FL) and standard (SL) length to the nearest $0.1 \mathrm{~cm}$ and weighed for the total wet body weight $(\mathrm{W})$ to the nearest $0.01 \mathrm{~g}$, and also their sex and age were determined.

To calculate the conversion factors between $\mathrm{TL}, \mathrm{FL}$,

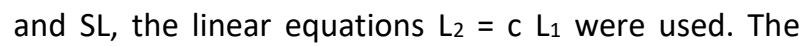
length-weight relationship (LWR) was estimated following the equation $W=a L^{b}$ transformed into log $W$ $=\log a+b \log T L$. Two different relationships were

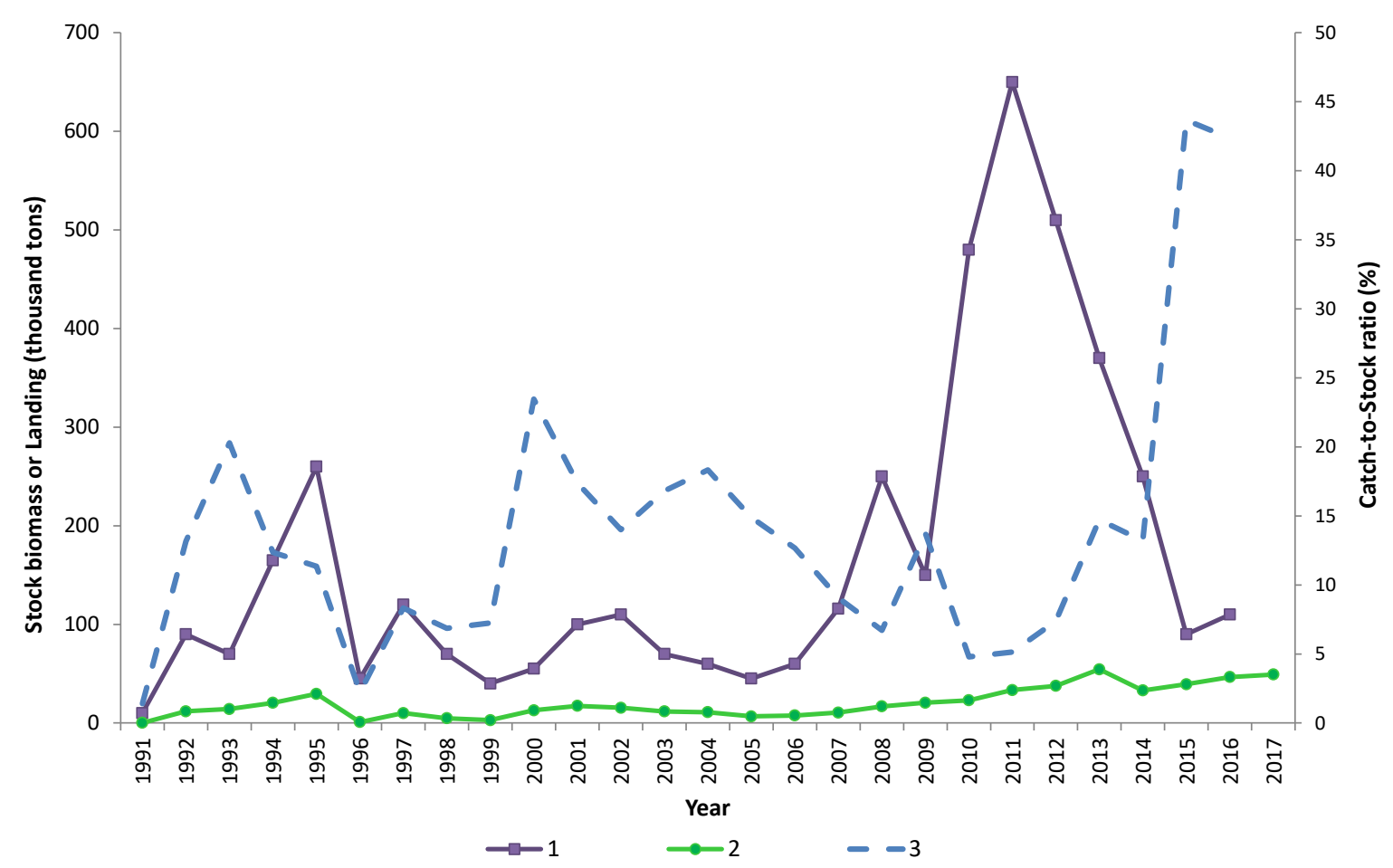

Figure 1. Stock biomass (1), Russian-Ukrainian landings (2) (from Chashchin et al., 2015; Shlyakhov et al., 2018) and catch-to-stock ratio (3) of Azov anchovy in 1991-2017. 
proposed for small $(T L<9.5 \mathrm{~cm})$ and larger fish separately. The "segmented" package for R-software allowed us to calculate the relationships and define a breakpoint between them (Muggeo, 2008).

The fish condition was assessed based on the relative condition factor $\mathrm{Kn}$ and content of total lipids in fish body. The $\mathrm{Kn}$ was estimated using the equation $\mathrm{Kn}=$ W/W (Le Cren, 1951) where the expected fish weight $\hat{W}$ was calculated by one of the formulas depending on fish size to make the $\mathrm{Kn}$ consistent across lengths. Then a logarithmic transformation was applied to $\mathrm{Kn}$ to eliminate the abnormality of the $\mathrm{Kn}$ distribution. To determine the lipid content (\% of wet weight), whole fish of each size group were minced in a blender, and the lipids were extracted with a chloroform-methanol mixture $(2: 1, \mathrm{vol} / \mathrm{vol}$ ) as previously described (Yuneva et al., 2019).

For age determination, whole otoliths were placed in glycerin and inspected under a stereomicroscope, counting annual rings. Age was recorded as group 0,1 , 2 and $3+$ years old. The birth date of anchovies was assumed to be $1^{\text {st }}$ July. Age-length keys (ALK) were calculated for the two seasons separately based on length-at-age data and number of fish in $0.5 \mathrm{~cm}$ fork length classes using R-software with the "alk" function from "fishmethods" package (Nelson, 2017; available at https://cran.r-project.org). The age compositions of anchovy for both seasons were calculated using the lenght-frequency distributions and corresponding ALKs. Length-at-age data also were used to estimate growth parameters in von Bertalanffy growth function $L_{t}=L_{\infty}[1$ $\left.-\mathrm{e}^{-\mathrm{K}(\mathrm{t}-\mathrm{to})}\right]$ and $\mathrm{W}_{\mathrm{t}}=\mathrm{W}_{\infty}\left[1-\mathrm{e}^{-\mathrm{K}(\mathrm{t}-\mathrm{t})}\right]^{\mathrm{b}}$, where $\mathrm{L}_{\mathrm{t}}$ and $\mathrm{W}_{\mathrm{t}}$ are the length and weight of fish at age $t ; L_{\infty}$ and $W_{\infty}$ are the asymptotic length and weight, $K$ is the instantaneous growth coefficient, and $t_{o}$ is the hypothetical age at which fish length is equal to 0 , and $b$ is the exponent of the length-weight relationship. The parameters $L_{\infty}, K$ and $t_{0}$ were calculated using R-software with the "growth" function in the "fishmethods" package (Nelson, 2017).

Standard statistical methods (summary statistics, normality tests, two-sample tests, etc.) were applied using the PAST ver. 3.25 software (Hammer, 2019; available at https://folk.uio.no/ohammer/past/). The Shapiro-Wilk test was performed to check the normality of the data. The Student t-test for equal means was used when the data followed a normal distribution. The Kolmogorov-Smirnov test was used to compare anchovy size distributions and the $\chi^{2}$ test was used to check the sex composition (Zar, 1999).

\section{Results}

\section{Length-Length Relationships}

Scientists use various measurements of fish body length as a basis for their research. Turkish scientists traditionally use the total length in anchovy studies while most Russian authors use the fork length or standard length. We calculated linear relationships between TL, FL, and SL for Azov anchovy to find conversion coefficients:

$$
\begin{array}{lll}
\mathrm{TL}=1.096 \mathrm{FL} & \mathrm{FL}=0.913 \mathrm{TL} & \mathrm{SL}=0.858 \mathrm{TL} \\
\mathrm{TL}=1.166 \mathrm{SL} & \mathrm{FL}=1.064 \mathrm{SL} & \mathrm{SL}=0.940 \mathrm{FL}
\end{array}
$$

The coefficients of determination $\left(R^{2}\right)$ were higher than 0.99 in all cases. Thus, for the Azov anchovy, FL is $91.3 \%$ of $T L$, and $\mathrm{SL}$ is $85.8 \%$ of TL or $94 \%$ of $\mathrm{FL}$.

\section{Length-Weight Relationships}

The average values of fish weight in different size classes was higher in the second fishing season 2017/2018 compared to the first one, with some exceptions (Table 2). These differences were statistically significant $(P<0.001)$ for size classes where the number of measured fish exceeded 100 individuals.

The length-weight relationship for all fish within the size range from 5.1 to $14.4 \mathrm{~cm} \mathrm{TL}$, for two seasons combined can be calculated as $W=0.0033 T^{3.206}$ (Figure 2a). However, an examination of residuals showed strong nonlinearity (Figure $2 \mathrm{~b}$ ), that related to differences in body shape between juveniles and adult fish. Therefore, with the "segmented" package, we calculated two

\begin{tabular}{|c|c|c|c|c|}
\hline Fishing season & Month & $\mathrm{N}$ of samples & $\mathrm{N}$ measured & $\mathrm{N}$ bioanalysis \\
\hline \multirow{6}{*}{$2016 / 2017$} & October & 6 & 643 & 182 \\
\hline & November & 6 & 772 & 142 \\
\hline & December & 7 & 874 & 165 \\
\hline & January & 3 & 522 & 123 \\
\hline & February & 2 & 287 & 140 \\
\hline & March & 3 & 528 & 168 \\
\hline \multirow{4}{*}{$2017 / 2018$} & October & 3 & 291 & 127 \\
\hline & November & 5 & 517 & 329 \\
\hline & January & 4 & 669 & 287 \\
\hline & February & 1 & 228 & 82 \\
\hline Total & & 40 & 5331 & 1745 \\
\hline
\end{tabular}

Table 1. Data on anchovy samples, number of measured and analyzed specimens. 
Table 2. Mean weight ( \pm SD) of Azov anchovy in different size classes in 2016/2017 and 2017/2018 fishing seasons.

\begin{tabular}{|c|c|c|c|c|c|}
\hline \multirow{3}{*}{$\begin{array}{l}\text { Size class } \\
(\mathrm{TL}, \mathrm{cm})\end{array}$} & \multicolumn{4}{|c|}{ Fishing season } & \multirow{3}{*}{$\begin{array}{c}t \text {-test } \\
(\mathrm{P})\end{array}$} \\
\hline & \multicolumn{2}{|c|}{$2016 / 2017$} & \multicolumn{2}{|c|}{$2017 / 2018$} & \\
\hline & $\mathrm{N}$ & Mean weight (g) & $\mathrm{N}$ & Mean weight (g) & \\
\hline $5.1-5.5$ & 5 & $0.61 \pm 0.08$ & 0 & - & - \\
\hline $5.6-6.0$ & 4 & $0.81 \pm 0.06$ & 0 & - & - \\
\hline $6.1-6.5$ & 3 & $1.15 \pm 0.15$ & 0 & - & - \\
\hline $6.6-7.0$ & 13 & $1.57 \pm 0.28$ & 5 & $1.72 \pm 0.19$ & 0.31 \\
\hline 7.1-7.5 & 16 & $2.25 \pm 0.34$ & 2 & $2.26 \pm 0.26$ & 0.78 \\
\hline $7.6-8.0$ & 25 & $2.69 \pm 0.39$ & 5 & $2.52 \pm 0.27$ & 0.98 \\
\hline $8.1-8.5$ & 12 & $3.48 \pm 0.66$ & 16 & $3.41 \pm 0.40$ & 0.98 \\
\hline $8.6-9.0$ & 16 & $3.90 \pm 0.53$ & 21 & $4.36 \pm 0.55$ & 0.72 \\
\hline $9.1-9.5$ & 19 & $5.30 \pm 0.87$ & 25 & $5.20 \pm 0.56$ & 0.54 \\
\hline 9.6-10.0 & 54 & $5.98 \pm 0.78$ & 48 & $6.05 \pm 0.72$ & 0.60 \\
\hline $10.1-10.5$ & 102 & $6.62 \pm 0.70$ & 105 & $6.98 \pm 0.69$ & $<0.001$ \\
\hline 10.6-11.0 & 148 & $7.27 \pm 0.95$ & 122 & $7.89 \pm 0.85$ & $<0.001$ \\
\hline $11.1-11.5$ & 203 & $8.04 \pm 1.12$ & 144 & $8.89 \pm 1.03$ & $<0.001$ \\
\hline $11.6-12.0$ & 143 & $8.99 \pm 1.34$ & 127 & $10.03 \pm 1.21$ & $<0.001$ \\
\hline $12.1-12.5$ & 71 & $9.83 \pm 1.15$ & 110 & $10.80 \pm 1.23$ & $<0.001$ \\
\hline $12.6-13.0$ & 22 & $11.02 \pm 1.07$ & 99 & $11.54 \pm 1.32$ & 0.17 \\
\hline $13.1-13.5$ & 5 & $12.25 \pm 0.70$ & 40 & $12.73 \pm 1.28$ & 0.43 \\
\hline $13.6-14.0$ & 0 & - & 11 & $13.98 \pm 2.50$ & - \\
\hline $14.1-14.5$ & 1 & 16.85 & 2 & $16.02 \pm 2.80$ & - \\
\hline
\end{tabular}
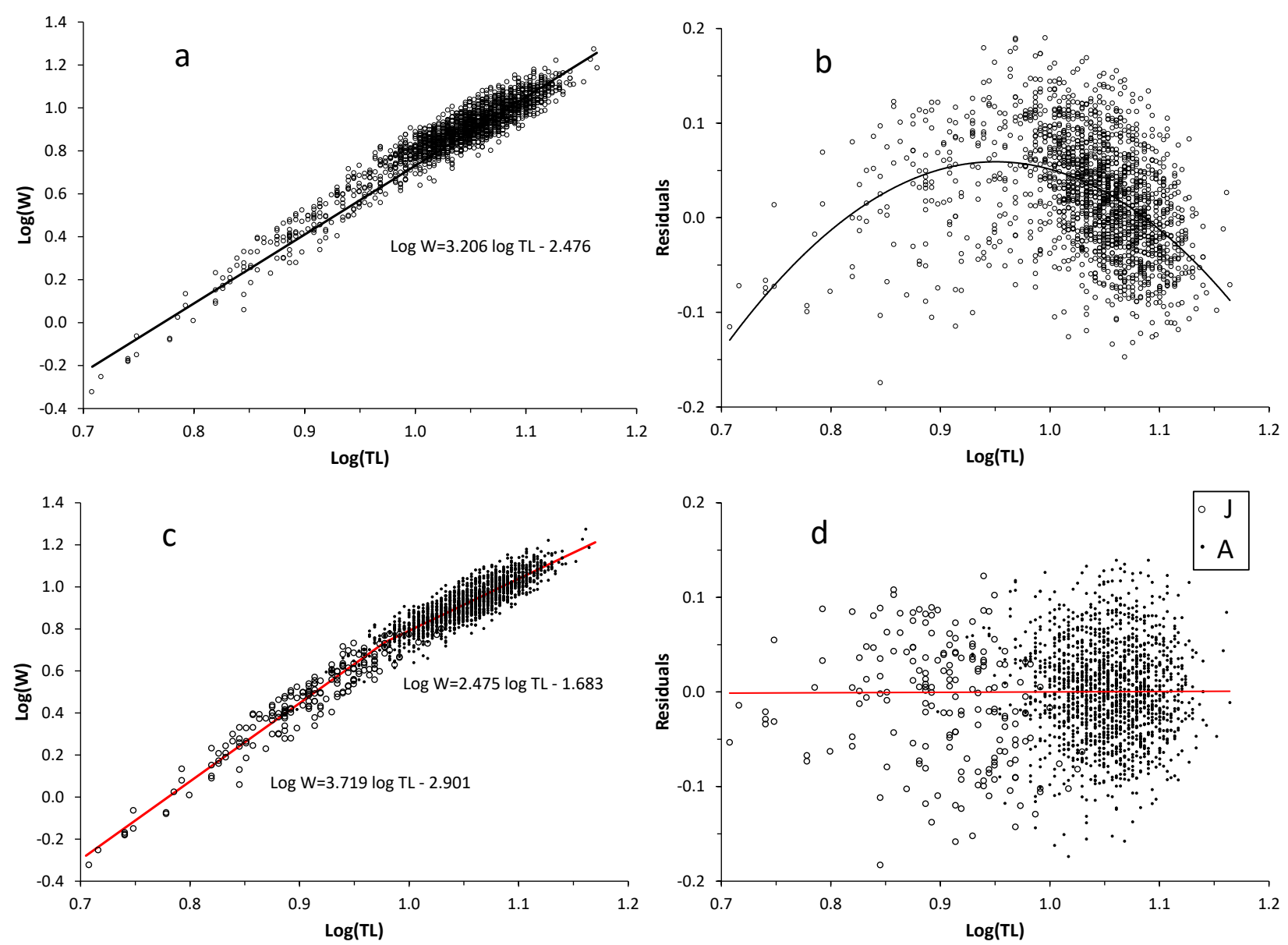

Figure 2. Double-logarithmic plot of anchovy weight vs total length based on all data (a) and absolute residuals (b), plot segmented on two lines for small and large fish (c) and absolute residuals (d). A break-point between two lines corresponds to $\mathrm{TL}=9.5 \mathrm{~cm}$. The symbols on plots below mean juveniles $(J)$ and adult $(A)$ fish. 
different regression lines that described the logtransformed data more accurately (Figure 2c). The calculated breakpoint between the lines corresponds to $9.5 \mathrm{~cm}$ TL. Thus, the LWR for fish $<9.5 \mathrm{~cm}$ TL was found as:

$$
W=0.00126 \mathrm{TL}^{3.719}
$$

and for larger fish

$$
W=0.0207 \mathrm{TL}^{2.475} \text {. }
$$

There was no statistically significant trend of residuals for such a segmented line (Figure $2 \mathrm{~d}$ ).

Thus, calculating $\mathrm{Kn}$ for small fish according to equation (1) and for large fish by equation (2), we obtained values that were independent of fish length.

No statistically significant differences were found between LWRs for either male or female. Thus, the generalized formula $\mathrm{W}=0.022 \mathrm{TL}^{2.45}$ can be used for mature fish longer than $8.5 \mathrm{~cm}$ TL.

\section{Size Composition}

The comparison of length-frequency distributions of Azov anchovy was conducted based on the fork length. The size distributions were significantly different for the two seasons (KS-test, $P<0.001$ ) (Figure 3). The modal size class in 2016/2017 was $9.5-10.0 \mathrm{~cm} \mathrm{FL,} \mathrm{while}$ in $2017 / 2018$ it increased to $10.5-11.0 \mathrm{~cm} \mathrm{FL}$. The relative abundance of fish larger $11.0 \mathrm{~cm}$ FL doubled in the second season ( $21 \%$ vs. $10 \%)$. Mean length of the anchovy was $9.88 \pm 0.41 \mathrm{~cm} \mathrm{FL}$ (or $10.82 \pm 0.45 \mathrm{~cm} \mathrm{TL}$ ) and weight was $7.60 \pm 1.10 \mathrm{~g}$ in $2016 / 2017$ while in the next season they increased to $10.37 \pm 0.35 \mathrm{~cm}$ FL $(11.36 \pm 0.38$ $\mathrm{cm} \mathrm{TL}$ ) and $8.91 \pm 0.92 \mathrm{~g}$. The differences between the means were significant according to $t$-test $(P<0.001)$. Mean anchovy lengths ranged monthly between 9.0 and $10.6 \mathrm{~cm}$ FL during 2016/2017 and 9.7-10.9 cm FL during $2017 / 2018$ and did not differ significantly within the studied seasons (ANOVA, $P=0.13$ and $P=0.63$ respectively).

Females were usually slightly larger than males (KStest, $P<0.05)$. The mean length of females in 2016/2017 was $11.19 \pm 0.99 \mathrm{~cm}$ TL and males $11.08 \pm 0.82 \mathrm{~cm} \mathrm{TL}$, whereas in $2017 / 2018$ it was $11.44 \pm 1.26 \mathrm{~cm}$ TL and $11.22 \pm 1.14 \mathrm{~cm}$ TL respectively. Both females and males were significantly larger in 2017/2018 than in the previous season (KS-test, $\mathrm{P}<0.001$ ).

The largest specimens of the Azov anchovy were found in 2017, they were 3-years old fish: female of 14.4 $\mathrm{cm} \mathrm{TL}$ and $16.85 \mathrm{~g}$ and a male of $14.5 \mathrm{~cm}$ TL and $18.82 \mathrm{~g}$.

\section{Age, Age Composition and Age-Length Keys}

According to the data of age determination using otoliths, the anchovy population consisted of four age groups $(0,1,2,3+)$.

The average length and weight of different age groups during various months are presented in Table 3. The results showed a small growth of the anchovy generations during the winter periods. Fingerlings born in 2016 increased their length from 7.6 to $8.15 \mathrm{~cm}$, while the generation of 2017 grew from 8.0 to $8.9 \mathrm{~cm}$. Older age groups grew less intensively, their increments were approximately 2-4 $\mathrm{mm}$ for the winters. At the same time, a decrease of mean body weight was observed in most cases in adult fish during wintering.

Overall, the average length and weight of each age group were notably larger in the fishing season

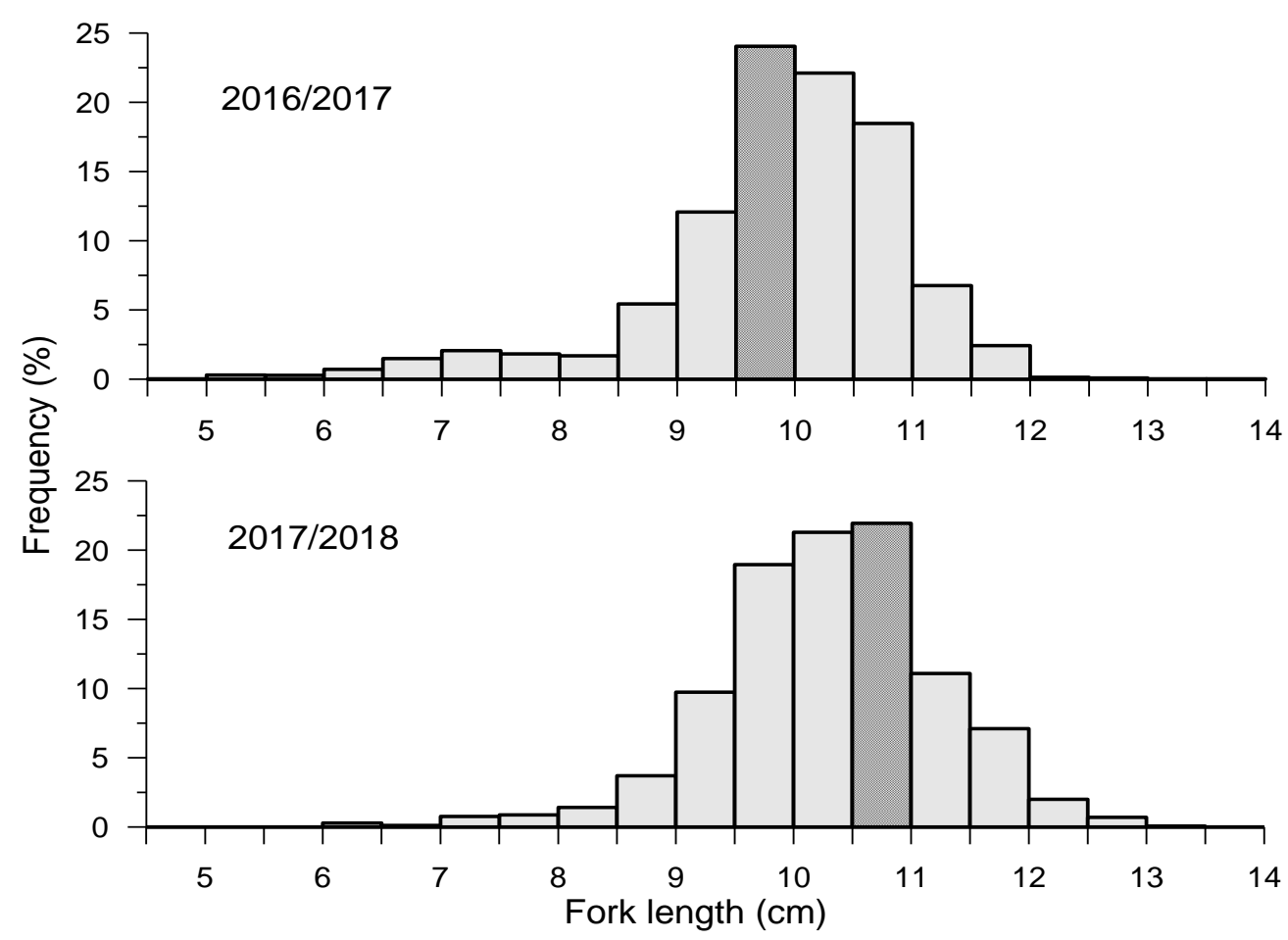

Figure 3. The length-frequency distribution of Azov anchovy in 2016/2017 and 2017/2018 fishing seasons. 
2017/2018 in comparison with previous season, except the average length of fish in the age group 1.

The age composition of Azov anchovy for each fishing season which was calculated using ALKs, is shown in Figure 4. In 2016/2017, age group 1 was dominated in catches (59.2\%), while age group 2 was less numerous (30.7\%). Fingerlings (age group 0) and the oldest age group $3+$ accounted for only a small portion of the catches $(8.0 \%$ and $1.9 \%$, respectively). In the next season, age group 2 was the most numerous (45.1\%), the share of age group 3 increased to $14.0 \%$, while the portion of 1-year's old fish decreased to $36.6 \%$.

\section{Sex Composition}

Out of 1529 specimens of Azov anchovy sexed for the two seasons, we recorded 733 males, 756 females, and 40 immature fingerlings. So, for both seasons combined, the sex ratio was very close to 1:1. However,

Table 3. Mean values of TL (cm) and weight (g) (underline) with standard errors of Azov anchovy by age groups in various months of 2016/2017 and 2017/2018 fishing seasons.

\begin{tabular}{|c|c|c|c|c|}
\hline \multirow{2}{*}{ Month } & \multicolumn{4}{|c|}{ Age group } \\
\hline & 0 & 1 & 2 & $3+$ \\
\hline & \multicolumn{4}{|c|}{ Fishing season 2016/2017 } \\
\hline \multirow{2}{*}{ October } & $\underline{7.60 \pm 0.23}$ & $\underline{10.55 \pm 0.14}$ & $\underline{11.26 \pm 0.11}$ & \multirow{2}{*}{-} \\
\hline & $2.77 \pm 0.24$ & $7.39 \pm 0.25$ & $8.53 \pm 0.18$ & \\
\hline \multirow{2}{*}{ November } & $\underline{7.29 \pm 0.13}$ & $\underline{10.62 \pm 0.08}$ & $\underline{11.60 \pm 0.07}$ & \multirow{2}{*}{-} \\
\hline & $2.36 \pm 0.14$ & $7.02 \pm 0.12$ & $8.93 \pm 0.23$ & \\
\hline \multirow{2}{*}{ December } & 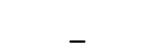 & $\underline{10.56 \pm 0.07}$ & $\underline{11.61 \pm 0.08}$ & \multirow{2}{*}{-} \\
\hline & - & $7.00 \pm 0.12$ & $9.07 \pm 0.16$ & \\
\hline \multirow{2}{*}{ January } & \multirow{2}{*}{-} & $11.04 \pm 0.06$ & $\underline{11.73 \pm 0.06}$ & $\underline{12.30 \pm 0.18}$ \\
\hline & & $7.54 \pm 0.12$ & $9.09 \pm 0.15$ & $10.19 \pm 0.69$ \\
\hline \multirow{2}{*}{ February } & \multirow{2}{*}{-} & $\underline{11.08 \pm 0.07}$ & $\underline{11.55 \pm 0.07}$ & $12.42 \pm 0.30$ \\
\hline & & $7.42 \pm 0.17$ & $8.66 \pm 0.15$ & $10.91 \pm 0.61$ \\
\hline \multirow{3}{*}{ March } & $\underline{8.15 \pm 0.21}$ & $\underline{10.59 \pm 0.06}$ & $\underline{11.86 \pm 0.06}$ & $\underline{12.71 \pm 0.15}$ \\
\hline & $2.75 \pm 0.25$ & $6.65 \pm 0.12$ & $9.04 \pm 0.14$ & $10.86 \pm 0.51$ \\
\hline & \multicolumn{4}{|c|}{ Fishing season $2017 / 2018$} \\
\hline \multirow{2}{*}{ October } & $\underline{8.00 \pm 0.14}$ & $\underline{10.45 \pm 0.08}$ & $\underline{11.65 \pm 0.07}$ & $\underline{12.50 \pm 0.12}$ \\
\hline & $3.03 \pm 0.30$ & $7.73 \pm 0.19$ & $10.53 \pm 0.18$ & $11.96 \pm 0.31$ \\
\hline \multirow{2}{*}{ November } & $\underline{8.69 \pm 0.15}$ & $\underline{10.38 \pm 0.06}$ & $\underline{11.60 \pm 0.06}$ & $\underline{12.52 \pm 0.09}$ \\
\hline & $4.15 \pm 0.23$ & $7.28 \pm 0.12$ & $9.44 \pm 0.13$ & $11.51 \pm 0.22$ \\
\hline \multirow{2}{*}{ January } & $\underline{8.36 \pm 0.17}$ & $\underline{10.59 \pm 0.07}$ & $\underline{11.95 \pm 0.07}$ & $\underline{12.58 \pm 0.09}$ \\
\hline & $3.67 \pm 0.23$ & $7.28 \pm 0.13$ & $9.67 \pm 0.14$ & $10.85 \pm 0.21$ \\
\hline \multirow{2}{*}{ February } & $\underline{8.91 \pm 0.21}$ & $\underline{10.62 \pm 0.09}$ & $\underline{11.93 \pm 0.10}$ & $\underline{12.76 \pm 0.10}$ \\
\hline & $\overline{3.77 \pm 0.27}$ & $\overline{6.92 \pm 0.18}$ & $9.13 \pm 0.22$ & $\overline{10.95 \pm 0.24}$ \\
\hline
\end{tabular}

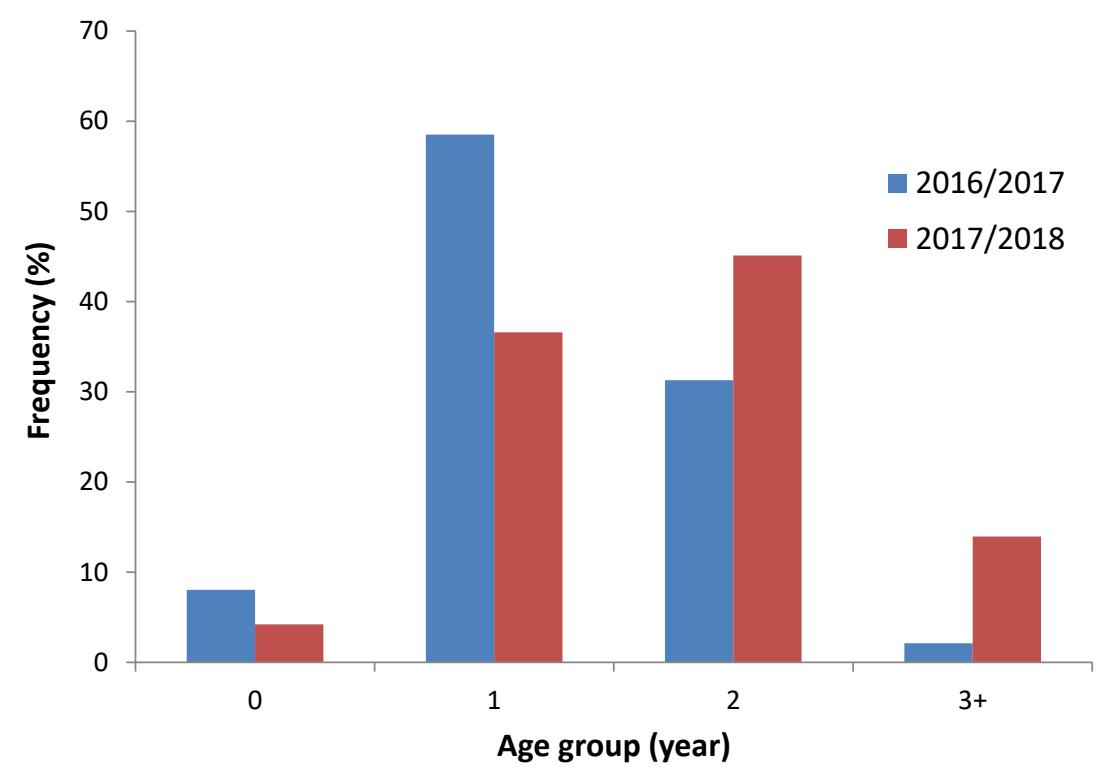

Figure 4. Age-frequency distribution of Azov anchovy in the two seasons. 
significant differences were observed between the two seasons $\left(\chi^{2}\right.$-test, $\left.\mathrm{P}<0.01\right)$. Males prevailed each month from October 2016 to March 2017 (52-58\%), while in $2017 / 2018$ the sex ratio shifted towards females, which dominated at $50-56 \%$ for the studied months.

\section{Fish Condition}

Mean values of $\mathrm{Kn}$ at the beginning of the fishing seasons (October-November), were 1.02 in 2016/2017 and 1.08 in 2017/2018 (Table 4). The Student's t-test showed that these means were statistically different ( $P$ $<0.0001$ ).

The lipid content in the anchovy body in OctoberNovember 2016 was $15.1 \%$, and in the same months of 2017, it was much higher, reaching $16.6 \%$.

Mean values of $\mathrm{Kn}$, as well as lipids, were decreasing in February-March to 0.94-0.95 and 13.7$13.8 \%$ respectively. The comparison of average values of $\mathrm{Kn}$ and lipids in the middle and end of 2016/2017 and $2017 / 2018$ wintering seasons did not show the significant difference due to the large variability.

It is worth to note that the lipid content related to fish size. Overall, the small fish $5.0-7.0 \mathrm{~cm}$ TL in OctoberNovember had the lowest values of lipids (on average <
9.0\%), fish of $8.0-12.0 \mathrm{~cm}$ TL had maximal values (14.5\%), and fish larger than $12 \mathrm{~cm}$ contained $12.0 \%$.

\section{Growth}

As was shown in Table 3, the average length and weight of the same age groups were greater in the second fishing season in most cases than in the first ones. Based on length-at-age data and using "growth" function in the "fishmethods" package of $R$, the von Bertalanffy growth equations for different fishing seasons were estimated as follow:

$$
\begin{array}{ll}
2016 / 2017 & \mathrm{TL}=12.2\left[1-\mathrm{e}^{-1.22(\mathrm{t}+0.38)}\right], \\
2017 / 2018 & \mathrm{TL}=14.0\left[1-\mathrm{e}^{-0.44(\mathrm{t}+1.67)}\right], \\
\text { Combined } & \mathrm{TL}=13.0\left[1-\mathrm{e}^{-0.73(\mathrm{t}+0.86)}\right]
\end{array}
$$

Despite the VBG parameters notably differed between seasons, the fitted growth curves were similar for fish older than 1 year (Figure 5). Therefore, the differences in values of VBG parameters were mainly related to differences in sizes of the age group 0 in various years.

Table 4. Mean relative condition factor $(\mathrm{Kn})$ and lipid content of Azov anchovy in selected months during the two fishing seasons.

\begin{tabular}{lcccccc}
\hline & \multicolumn{3}{c}{ Condition factor Kn } & \multicolumn{3}{c}{ Lipids (\% wet weight) } \\
\cline { 2 - 7 } Season & $2016 / 2017$ & $2017 / 2018$ & $t$-test & $2016 / 2017$ & $2017 / 2018$ & $t$-test \\
\hline Oct - Nov & $1.020 \pm 0.016$ & $1.080 \pm 0.010$ & $\mathrm{P}<0.0001$ & $15.1 \pm 3.0$ & $16.6 \pm 2.9$ & $\mathrm{P}=0.08$ \\
Dec- Jan & $0.980 \pm 0.012$ & $1.007 \pm 0.011$ & $\mathrm{P}=0.0014$ & $15.4 \pm 2.1$ & $15.1 \pm 1.1$ & $\mathrm{P}=0.75$ \\
Feb - Mar & $0.938 \pm 0.011$ & $0.949 \pm 0.017$ & $\mathrm{P}=0.33$ & $13.8 \pm 1.1$ & $13.7 \pm 1.4$ & $\mathrm{P}=0.75$ \\
\hline
\end{tabular}

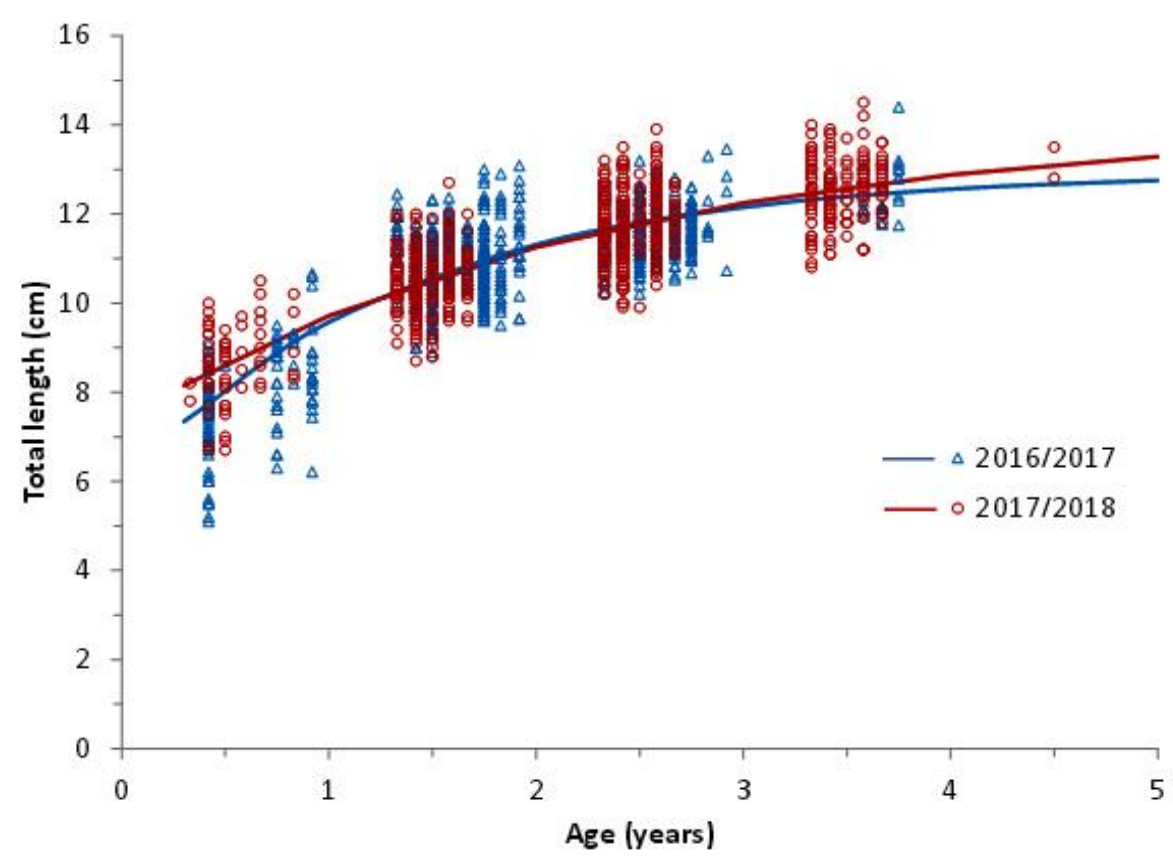

Figure 5. Length-at-age of Azov anchovy in 2016/2017 and 2017/2018 fishing seasons and fitted growth curves. 
In fact, these curves do not describe the growth rate of a single cohort or individual fish, but allow you to compare the length of the age of the Azov anchovy with other subspecies of anchovies.

Actually, these curves do not describe the growth rate of a single cohort or an individual fish but allow us to compare the length-at-age of Azov anchovy with other anchovy subspecies.

\section{Discussion}

The Azov Sea ecosystem has recently undergone changes due to an increase in the water salinity from 9.4 ppm in 2006 to 13.8 ppm in 2017 (Kosenko et al., 2017). Initially, the salinization of the Sea of Azov had a positive impact on the population of Azov anchovy. Its spawning and feeding grounds have expanded, the quality and quantity of food have improved due to the increase in the penetration of the Black Sea plankton into the Sea of Azov and the reduction of trophic competition with ctenophore-invader Mnemiopsis leidyi and fish Clupeonella cultriventris (Yuneva et al., 2019). These changes in the Azov ecosystem initially promoted an unprecedented increase in the stock biomass of Azov anchovy in 2010-2012, but have since declined dramatically in 2015-2016 (see Figure 1). Obviously, the water salinity in the Sea of Azov also plays an important role in the distribution of spawning and feeding grounds of the anchovy, the survival of fish larvae and the recruitment yield.

Environmental factors, especially the sea surface temperature, play a major role in the dynamics of anchovy stocks (Gursalan et al., 2014). Recent data indicate that climate changes affect the location of spawning and overwintering grounds, as well as the timing and migration pathways of the anchovies, and ultimately the fishing success (Gücü et al., 2016; Gursalan et al., 2017).

In addition to environmental factors, fishing can have a significant impact on fish populations. The results of this work showed that despite very large landings of the anchovy in 2015 and 2016, the average length and weight of the fish in catches were significantly greater than in 2010-2012 when the stock biomass was maximal and the catch to stock ratio was the lowest. The average size of anchovies in 2010-2012 was $9.1 \mathrm{~cm}$ FL (Yuneva et al., 2019), while in 2016/2017 it was $9.9 \mathrm{~cm}$ and even increased to $10.4 \mathrm{~cm}$ in 2017/2018. Also, the average weight of fish in catches increased from $6.6 \mathrm{~g}$ to 7.6 and $8.9 \mathrm{~g}$, respectively. Besides, the maximum size of Azov anchovy recorded in the present study was $14.5 \mathrm{~cm} \mathrm{TL}$ and $18.82 \mathrm{~g}$ that is greater than the maximum reported length of the Azov anchovy in the literature as $14 \mathrm{~cm}$ (Svetovidov, 1964).

Azov anchovy is a fish with a short lifespan, and fish in our study were represented by individuals aged 0 to 4 year's old, as expected. Anchovy fisheries were based on 1-year's old fish (59.2\%) in 2016/2017 and 2-year's old fish $(45.1 \%)$ in $2017 / 2018$. So, the recruitment to the stock in 2015 was quite strong and supported fisheries in the next two seasons, comprising $56 \%$ of the catch biomass in 2016/2017 and 50\% in 2017/2018. However, there was no successful recruitment in 2016 and 2017.

The size composition of anchovy did not show any significant differences between months within the studied seasons. A slight increase in length for all anchovy generations was observed during wintering, especially in age group 0 , but the mean body weight was decreased in most cases at the same time. Generally, the average length and weight of each age group were significantly larger in the fishing season 2017/2018 in comparison with the previous season.

There are numerous studies on length-weight relationship for the Black Sea anchovy, while published data for Azov anchovy are practically absent. We found only one paper (Volovik \& Kozlitina, 1983), which reported the value of coefficient $b$ for Azov anchovy in the range of 2.56-2.89. So, we compared our results with literature data on the Black Sea anchovy (Table 5). According to our calculations, adult specimens of Azov anchovy were lighter in weight than the Black Sea anchovy at the same length (Figure 6). This may be related by a higher content of lipids in Azov anchovy than in the Black Sea anchovy (Yuneva et al., 2013), because its specific body weight is lower, as fat is lighter than other tissues.

The present study indicates that young anchovies up to $9.5 \mathrm{~cm}$ TL had a positive allometric growth $(\mathrm{b}=$ 3.719), while adult fish $>9.5 \mathrm{~cm}$ had the negative allometric growth $(b=2.475)$. This can be explained by different growth strategies of immature young and mature adult fish. Somatic growth in body length prevails in young individuals to grow faster and avoid predators, and $9.5 \mathrm{~cm}$ is approximately the largest length of fingerlings (age group 0). The strategy of adults is focused on the fat accumulation, production of gonads and reproduction. So, in this case, is better to use different LWR equations and calculate the relative condition factor $(\mathrm{Kn})$ instead of Fulton condition factor. Overall, the body condition of Azov anchovy estimated by $\mathrm{Kn}$ and content of total lipids was higher in the beginning (October-November) of second fishing season 2017/2018 and gradually decreased to February-March in both seasons due to the low feeding intensity, weight and lipid losses. According to Shul'man (1974), this pattern is common for warm-water fishes and the lipid content in the anchovy body is reached its maximum values in October-November, therefore this parameter is used as an indicator of the feeding success before wintering. From Yuneva et al. (2019), the lipid content reached more than $18 \%$ in $2010-2012$, when the stock biomass of Azov anchovy were at the maximum level. The current decrease of lipid content to about $15-16 \%$ indicated the deterioration in the food supply of the anchovy in 2016 and 2017.

As well as LWR parameters, published data on the growth of Azov anchovy are very rare. For the first time, parameters of von Bertalanffy equation were calculated 
Table 5. Parameters of the length-weight relationship (LWR) and the von Bertalanffy growth equation (VBG) for Azov anchovy and the Black Sea anchovy.

\begin{tabular}{|c|c|c|c|c|c|c|c|}
\hline \multirow[b]{2}{*}{ Period } & \multicolumn{3}{|c|}{ LWR parameters } & \multicolumn{3}{|c|}{ VBG parameters } & \multirow[b]{2}{*}{ Source } \\
\hline & $a$ & $b$ & $\begin{array}{c}L_{\infty} \\
(\mathrm{cm})\end{array}$ & $\begin{array}{l}W_{\infty} \\
(\mathrm{cm})\end{array}$ & $\begin{array}{c}K \\
\left(\mathrm{yr}^{-1}\right)\end{array}$ & $\begin{array}{c}t_{0} \\
(\mathrm{yr})\end{array}$ & \\
\hline \multicolumn{8}{|c|}{ Azov Sea anchovy } \\
\hline- & - & - & 11.70 & - & 1.16 & -0.17 & $\begin{array}{l}\text { Bayliff (1967), on data from Berg et al. } \\
\text { (1949) }\end{array}$ \\
\hline- & - & - & 9.40 & - & 1.21 & -0.37 & $\begin{array}{c}\text { Bayliff (1967), on data from } \\
\text { Svetovidov, } 1964\end{array}$ \\
\hline \multirow{3}{*}{$1932-77$} & - & 2.89 & - & 9.0 & 0.31 & -1.82 & \\
\hline & - & 2.87 & - & 13.3 & 0.57 & -1.42 & \multirow{2}{*}{ Volovik \& Kozlitina (1983) } \\
\hline & - & 2.56 & - & 26.2 & 0.78 & -1.11 & \\
\hline 1967-77 & - & - & 13.26 & 22.6 & 0.61 & -1.80 & \\
\hline 2016-18 & 0.022 & 2.45 & 13.00 & 12.6 & 0.73 & -0.86 & Present study \\
\hline \multicolumn{8}{|c|}{ Black Sea anchovy } \\
\hline $1977-85$ & - & - & 13.90 & 20.0 & 0.99 & -0.74 & Shlyakhov et al. (1990) \\
\hline $1985 / 86$ & 0.0023 & 3.416 & 16.77 & - & 0.32 & -2.07 & Erkoyuncu \& Özdamar (1989) \\
\hline $1986 / 87$ & 0.0025 & 3.383 & 16.85 & 34.48 & 0.32 & -1.99 & Karaçam \& Düzgüneş (1990) \\
\hline $1987 / 88$ & 0.0025 & 3.387 & 14.14 & 20.04 & 0.92 & -0.32 & Düzgüneş \& Karaçam (1989) \\
\hline $1988 / 89$ & 0.0064 & 2.974 & 15.73 & 23.32 & 0.32 & -2.19 & Ünsal (1989) \\
\hline $1993 / 94$ & 0.0051 & 3.048 & 15.82 & 23.07 & 0.34 & -2.14 & Düzgüneş et al. (1995) \\
\hline 1994/95 & 0.0047 & 3.098 & 16.83 & 29.47 & 0.31 & -2.21 & Özdamar et al. (1995) \\
\hline 1998/99 & 0.0083 & 2.872 & 15.66 & - & 0.34 & -2.53 & \multirow{3}{*}{ Samsun et al. (2004) } \\
\hline 1999/00 & 0.0076 & 2.919 & 17.07 & - & 0.28 & -2.10 & \\
\hline 2000/01 & 0.0118 & 2.710 & 16.84 & - & 0.23 & -3.08 & \\
\hline 2001/02 & 0.0051 & 3.057 & 18.46 & - & 0.22 & -2.86 & \multirow[t]{2}{*}{ Samsun et al. (2006) } \\
\hline $2002 / 03$ & 0.0075 & 2.895 & 18.73 & - & 0.16 & -3.97 & \\
\hline 2004/05 & 0.0101 & 2.790 & 21.17 & - & 0.20 & -2.31 & Bilgin et al. (2006) \\
\hline 2004/05 & 0.0101 & 2.794 & 16.11 & 23.88 & 0.29 & -2.56 & \multirow{2}{*}{ Şahin et al. (2008) } \\
\hline $2005 / 06$ & 0.0055 & 3.0425 & 15.27 & 21.99 & 0.28 & -3.53 & \\
\hline $2006 / 10$ & 0.024 & 2.507 & 14.60 & - & 0.48 & -1.55 & Yankova (2014), Yankova et al. (2011) \\
\hline $2010 / 11$ & 0.011 & 2.742 & 16.37 & 23.52 & 0.43 & -1.35 & Sağlam \& Sağlam (2013) \\
\hline $2005-16$ & 0.0046 & 3.122 & - & - & - & - & Gücü et al. (2018) \\
\hline $2008-11$ & 0.0124 & 2.711 & 16.52 & - & 0.36 & -2.02 & Kasapoğlu (2018) \\
\hline
\end{tabular}

by Bailiff (1967) on the basis of length-at-age data reported by Berg et al. (1949) and Svetovidov (1964) (see Table 5). These data were later compiled by Pauly (1978) and included in FishBase (Froese \& Pauly, 2019). Later, the growth data for Azov anchovy were reported by Volovik and Kozlitina (1983). They found significant differences in growth rates between different cohorts and showed characteristic values for "accelerated", "moderate" and "weak" growth. According to our results, anchovy growth in 2016/2017 and 2017/2018 seasons appeared similar to "moderate" growth following Volovik and Kozlitina (1983). To compare growth rates between Azov and the Black Sea anchovies, we also included in Table 5 some literature data on VBG parameters of the Black Sea anchovy. The major differences between the subspecies were observed in the values of asymptotic length which in Azov anchovy were ranged between $9.4-14.0 \mathrm{~cm}$, while for the Black Sea anchovy were notably higher ranging from 13.9 to $21.2 \mathrm{~cm}$. The recent overview of the Black Sea anchovy (Bilgin et al., 2016) demonstrated changes in the mean length at age of anchovy caught in waters of Turkey from 1985 to 2011. Our data on mean length of Azov anchovy are within the ranges pointed by these authors for age groups 0 and 1 , but smaller than in older age groups. Based on data from Table 5, we plotted a comparative picture showing the growth curves of Azov anchovy on the background of the range of growth curves for the Black Sea anchovy (Figure 7). The growth rate of Azov anchovy seems to be similar to the Black Sea anchovy for the age groups 0 and 1, but declined for fish of the oldest age groups.

Observed changes in the Azov anchovy population structure and the fluctuation of the stock biomass are likely related to environmental conditions rather than to fishing pressure. However, we believe that the continuation of fishing of Azov anchovy at the current level would adversely affect the size-age structure, reduce biological growth rate and inevitably lead to overfishing and depletion of the stock.

\section{Acknowledgements}

This work was conducted within the framework of the state task of the A.O. Kovalevsky Institute of Biology 


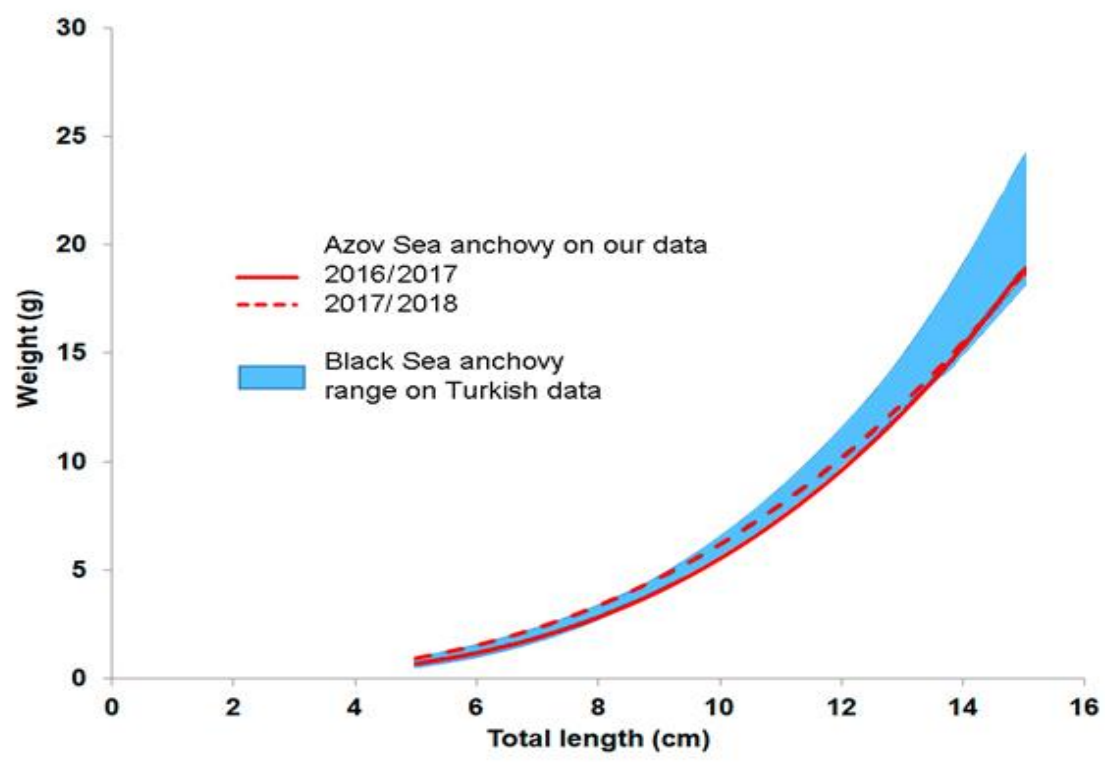

Figure 6. The length-weight relationships of the Azov anchovy in comparison with the range of combined LWR data for the Black Sea anchovy (drawn according to data from Table 5).

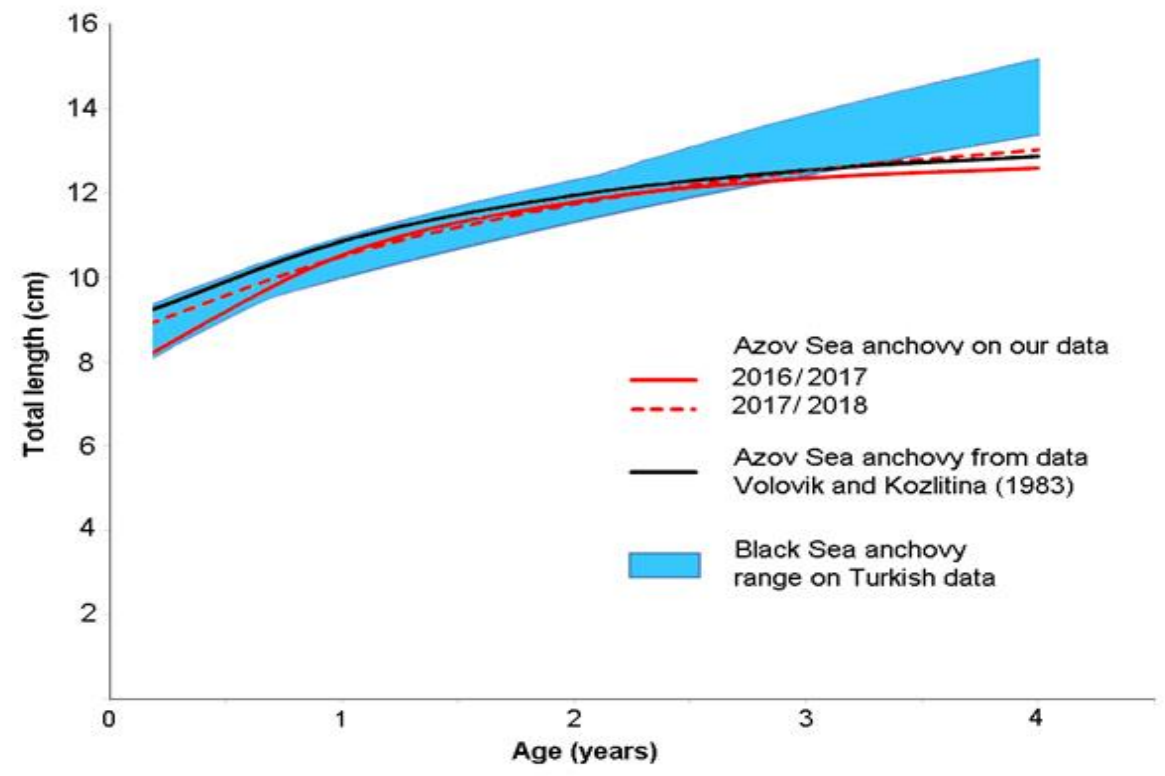

Figure 7. Growth curves of Azov anchovy in comparison with the range of growth curves of the Black Sea anchovy (drawn according to data from Table 5).

of the Southern Seas, the theme "Functional, metabolic and toxicological aspects of hydrobionts and their populations in biotopes with different physico-chemical regimes" (NIOKTR Reg.No. AAAA-A18-118021490093-4) and supported by the project of RFFI Reg.No. 18-44920022 "The response of the Black Sea pelagic ecosystem to climate changes in the region (on the example of jellyfish, ctenophores and small pelagic fishes)". We are very grateful to Dr. L.I. Bulli for providing anchovy samples.

\section{References}

Bayliff, W.H. (1967). Growth, mortality and exploitation of the Engraulidae, with special reference to the anchoveta, Cetengraulis mysticetus, and the Colorado, Anchoa naso, in the eastern Pacific Ocean. Bulletin Inter-American Tropical Tuna Commission, 12(5), 365-432.

Berg, L.S., Bogdanov, L.S., Kozhin, N.I. \& Rass, T.S. (1949). Commercial Fishes of the USSR. Description of the Fishes. (Promslovye Ryby SSSR. Opisaniya Ryb), Pishchepromizdat, 787 pp. (in Russian). 
Bilgin, S., Samsun, N., Samsun, O. \& Kalayci, F. (2006). Estimation of population parameters of anchovy, Engraulis encrasicolus L. 1758, at 2004-2005 fishing season in the Middle Black Sea, using length frequency analysis methods. E.U. Journal of Fisheries \& Aquatic Sciences, 23, 359-364.

http://dx.doi.org/10.12714/egejfas.2006.23.3.5000156 840 (in Turkish).

Bilgin, S., Sumer, C., Bektas, S., Satilmis, H. H. \& Bircan, R. (2016). Evaluation of anchovy (Engraulis encrasicolus) population dynamics studies (1985-2015) in terms of fisheries management in the Black Sea. Ege Journal of Fisheries and Aquatic Sciences, 33, 169-182. http://dx.doi.org/10.12714/egejfas.2016.33.2.12 (in Turkish).

Chashchin, A. (1996). The Black Sea populations of anchovy. Scientia Marina, 60(2), 219-225.

Chashchin, A.K., Shlyakhov, V.A., Dubovik, V.E. \& Negoda, S. (2015). Stock assessment of anchovy (Engraulis encrasicolus L.) in northern Black Sea and Sea of Azov. Chapter 6. In I. Zlateva, V. Raykov \& N. Nykolov (Eds.), Progressive engineering practices in marine resource management (pp. 209-243). Hershey, PA: IGI Global, 455 pp. $\quad$ http://dx.doi.org/10.4018/978-1-4666-83334.ch006.

Dement'eva, T.F. (1958). Methods of studying the influence of natural factors on the population of the Azov anchovy. Proceedings of VNIRO, 44, 30-62 (in Russian).

Düzgüneş, E. \& Karaçam, H. (1989). Karadeniz'deki hamsi (Engraulis encrasicolus L. 1758) balıklarında bazı populasyon büyüme özelliklerinin inncelenmesi. Doğa Zoology, 13, 77-83 (in Turkish).

Düzgüneş, E., Mutlu, C. \& Şahin, C. (1995). Population parameters of anchovy in the Eastern Black Sea. Proceedings of Second International Conference on the Mediterranean Coastal Environment, MEDCOAST 1995, 24-27 October, At Tarragona, Spain, 59-66.

Düzgüneş, Z.D., Eroğlu, O., Firidin, Ş. \& Çakmak, E. (2018). Genetic diversity for anchovy populations (Engraulis encrasicolus L.) in the Azov, Marmara and Black Sea. Genetics of Aquatic Organisms, 2, 53-60. http://dx.doi.org/10.4194/2459-1831-v2_2_05.

Erkoyuncu, I. \& Özdamar, E. (1989). Estimation of the age, size and sex composition and growth parameters of anchovy Engraulis encrasicolus (L) in the Black Sea. Fishery Research, 7, 41-247. http://dx.doi.org/10.1016/01657836(89)90058-1.

Froese, R. \& Pauly, D. (2019). FishBase. World Wide Web electronic publication. Retrieved from http://www.fishbase.org, version (02/2019).

GFCM (2014). Stock assessment form small pelagics - Anchovy 2012-2013. Black Sea Ukrainian waters. Ver. 0.9. GFCMFAO, $21 \mathrm{pp}$.

Gücü, A.C., Inanmaz, Ö.E., Ok, M. \& Sakinan, S. (2016). Recent changes in the spawning grounds of Black Sea anchovy, Engraulis encrasicolus. Fisheries Oceanography, 25(1), 67-84. https://doi.org/10.1111/fog.12135.

Gücü, A.C., Genç, Y., Dağtekin, M., Sakınan, S., Ak, O., Ok, M. \& Aydın, i. (2017). On Black Sea anchovy and its fishery. Reviews in Fisheries Science \& Aquaculture, 25:3, 230244. http://dx.doi.org/10.1080/23308249.2016.1276152.

Gücü, A.C., Genç, Y., Başçınar, N.S., Dağtekin, M., Atılgan, E., Erbay, M., Kutlu, S. (2018). Inter and intra annual variation in body condition of the Black Sea anchovy,
Engraulis encrasicolus ponticus - Potential causes and consequences. Fisheries Research, 205, 21-31. http://dx.doi.org/10.1016/j.fishres.2018.03.015.

Guraslan, C., Fach, B. A., and Oguz, T. (2014). Modeling the impact of climate variability on Black Sea anchovy recruitment and production. Fisheries Oceanography, 23, 436-457. http://dx.doi.org/10.1111/fog.12080.

Guraslan, C., Fach, B.A. \& Oguz, T. (2017). Understanding the impact of environmental variability on anchovy overwintering migration in Black Sea and its implications for the fishing industry. Frontiers in Marine Science, 4(275), 1-24. http://dx.doi.org/10.3389/fmars.2017.00275.

Hammer, $\varnothing$. (2019). PAST: Paleontological Statistics. Ver. 3.25. Reference manual. Natural History Museum University of Oslo, 275 pp. Retrieved from https:/folk.uio.no/ohammer/past/past3 manual.pdf.

Karaçam, H. \& Düzgüneş, E. (1990). Age, growth and meat yield of European anchovy (Engraulis encrasicolus L., 1758) in the Black Sea. Fisheries Research, 9, 181-186. http://dx.doi.org/10.1016/0165-7836(90)90063-2.

Kasapoğlu, N. (2018). Age, growth, and mortality of exploited stocks: anchovy, sprat, Mediterranean horse mackerel, whiting, and red mullet in the southeastern Black Sea. Aquatic Sciences and Engineering, 33(2), 39-49. http://dx.doi.org/10.18864/ASE201807.

Kosenko, J.V., Barabashin, T.O. \& Baskakova, T.E. (2017). Dynamics of hydrochemical characteristics of the Sea of Azov in modem period of salinization. News of NorthCaucasus institutes (Izvestiya vuzov. Severo-Kavkazskii regiona), 3(1), 76-82 (in Russian).

Kornilova, V.P. (1960). Biology and fishery of the Azov anchovy. Proceedings of the AzcherNIRO, 18, 50-73 (in Russian).

Nelson, G.A. (2017). Fishery science methods and models in R. Package 'fishmethods'. Ver.1.10-4. October 2017. Retrieved from http://cran.rproject.org/web/packages/fishmethods/index.html.

Le Cren, E.D. (1951). The length-weight relationship and seasonal cycle in gonad weight and condition in the perch (Perca fluviatilis). Journal of Animal Ecology, 20, 201-219. http://dx.doi.org/10.2307/1540.

Muggeo M. R. (2008) segmented: An R package to fit regression models with broken-Line relationships. $\mathrm{R}$ News, 8/1, 20-25.

Özdamar, E., Samsun, O. \& Erkoyuncu, I. (1995). The estimation of population parameters for anchovy (Engraulis encrasicolus, L.) during 1994-1995 fishing season in the Turkish Black Sea region. Ege Journal of Fisheries and Aquatic Sciences, 12 (1-2), 135-144 (in Turkish).

Pauly, D. (1978). A preliminary compilation of fish length growth parameters. Ber. Inst. Meereskd. ChristianAlbrechts-Univ. Kiel (55), 200 pp.

Popova, V.P. (1954). The Black Sea period of the life of the Azov anchovy. Proceedings of the VNIRO, 28, 65-74 (in Russian).

Sağlam E.N. \& Sağlam, C. (2013). Age, growth and mortality of anchovy Engraulis encrasicolus in the south-eastern region of the Black Sea during the 2010-2011 fishing season. Journal of the Marine Biological Association of the United Kingdom, 93(8), 2247-2255. http://dx.doi.org/10.1017/S0025315413000611.

Şahin, C., Akın, S., Hacımurtazaoğlu1, N., Mutlu, C. \& Verep, B. 2008. The stock parameter of anchovy (Engraulis encrasicolus) population on the coasts of the eastern 
Black sea: reason and implications in declining of anchovy population during the 2004-2005 and 20052006 fishing seasons. Fresenius Environmental Bulletin, 17(12b), 2159-2168.

Samsun, O., Samsun, N. \& Karamollaoğlu, A.C. (2004). Age, growth and mortality rates of the European anchovy (Engraulis encrasicolus L. 1758) in the Turkish Black Sea coast. Turkish Journal of Veterinary and Animal Sciences, 28(5), 901-910.

Samsun, O., Samsun, N., Kalaycı F. \& Bilgin, S. (2006). A study on recent variations in the population structure of European anchovy (Engraulis encrasicolus L., 1758) in the southern Black Sea. Ege Journal of Fisheries and Aquatic Sciences, 23(3-4), 301-306.

Shlyakhov, V.A. (2015). On the preparation of substantiations for possible catches of aquatic biological resources in the sea areas adjacent to the Crimean Peninsula. Proceedings of the YugNIRO, 53, 34-45 (in Russian).

Shlyakhov, V.A., Chashchin, A.K. \& Korkosh, N.I. (1990). Intensity of fisheries and dynamics of the Black Sea anchovy stocks. In V.A. Shlyakhov (Ed.). Biological resources of the Black Sea (pp. 93-102). Moscow: VNIRO, 192 pp. (in Russian).

Shlyakhov, V.A., Shlyakhova, O.V., Nadolinsky, V.P. \& Perevalov, O.A. (2018). Fishery and biological parameters of the fisheries, targeting the most important shared stocks of aquatic bioresources of the Black Sea as a basis for their regional assessment. Aquatic Bioresources and Environment, 1(1), 86-103 (in Russian).

Shul'man, G.E. (1974). Life cycles of fish. Physiology and biochemistry. Hulsted Press, John Wiley and Sons, NewYork Press., $253 \mathrm{pp}$.

STECF (2015). Black Sea assessments (STECF-15-16). Publications Office of the European Union, Luxembourg, EUR 27517 EN, JRC 98095, 284 pp.

Svetovidov, A.N. (1964). Handbook of the fauna of the USSR, 86. Fishes of the Black Sea (Opredeliteli po faune SSSR, 86. Ryby Chernogo Morya). Nauka, Moscow, 550 pp.

Ünsal, N. (1989). A study on age-length-weight relationship and determination of the smallest catching size of anchovy, Engraulis encrasicolus (L.) in the Black Sea. Istanbul University, Journal of Aquatic Products, 3(1-2), 17-28 (in Turkish).

Vodyasova E.A., Soldatov A.A. 2017. Identification of subspecies of European anchovy Engraulis encrasicolus
(Engraulidae) in the wintering aggregations based on morphological parameters of otoliths. Journal of Ichthyology, 57(4), 553-559.

http://dx.doi.org/10.1134/S0032945217040191.

Volovik, S.P. \& Kozlitina, S.V. (1983). Assessment of the potential catch of the Azov anchovy, Engraulis encrasicolus (Engraulidae), in relation to growth and structure of its population. Voprosy Ihtiologii, 23(1), 2638 (in Russian).

Yankova, M. (2014). Preliminary estimates of the population parameters of four species in the Bulgarian Black Sea coast. International Journal of Latest Research in Science and Technology, 3(5), 46-52.

Yankova, M., Pavlov, D., Raykov, V., Mihneva, V. \& Radu, G. (2011). Length-weight relationships of ten fish species from the Bulgarian Black Sea waters. Turkish Journal of Zoolology, 35(2), 265-270.

http://dx.doi.org/10.3906/zoo-0912-44.

Yuneva, T.V., Shchepkina, A.M., Zabelinsky, S.A., Nikolsky, V.N., Bat, L., Kaya, Ya., Seyhan, K. \& Shulman, G.E. (2013). Phospholipid fatty acid content of the Sea of Azov anchovy Engraulis encrasicolus maeoticus Pusanov and Black Sea anchovy Engraulis encrasicolus ponticus Alexandrov during fishing period 2006-2011. Morskoj ehkologicheskij zhurnal (Marine Ecological Journal), 12(2), 88-99 (in Russian).

Yuneva, T.V., Nikolsky, V.N., Zabelinsky, S.A., Shchepkina, A.M., Bulli, L.I. \& Shulman, G.E. (2019). Interannual variability of lipids and fatty acids in Azov anchovy Engraulis encrasicolus maeoticus (Engraulidae) under current salinization of the Sea of Azov. Journal of Ichthyology, 59(1), 104-112. http://dx.doi.org/10.1134/S003294521901017X.

Zar, J.H. (1999). Biostatistical Analysis. Prentice Hall, New Jersey, $663 \mathrm{pp}$.

Zuyev, G.V. (2014). Intraspecific differentiation and distribution of the European anchovy Engraulis encrasicolus in the Black and Azov seas. Morskoj ehkologicheskij zhurnal (Marine Ecological Journal), 13(3), 19-31 (in Russian).

Zuyev, G.V., Bondarev, V.A., Murzin, Y.L. \& Samotoy, Y.V. (2014). Long-term and annual variability of intraspecific and biological structures of anchovy Engraulis encrasicolus (L.) (Pisces: Engraulidae), wintering off the east coast of Crimea. Morskoj ehkologicheskij zhurnal (Marine Ecological Journal), 13(2), 31-40 (in Russian). 